UDC 378.147::811.111](497.11)

Milica Stojanović

University of Belgrade, Serbia

\title{
HORTUS CONCLUSUS: A VISUAL DISCOURSE ANALYSIS BASED ON A CRITICAL LITERACY APPROACH TO EDUCATION
}

\begin{abstract}
Some form of critical literacy seems to have become essential to all students today, irrespective of where they are studying, at what level, or what their academic field is. Indeed, in even greater need of developing their critical literacy abilities appear to be students of the Humanities for it is in these areas of study that some critical, cultural and historical perspectives are constantly being re-examined, reassessed, deconstructed and reconstructed in accordance with our age/postmodern/modern theories. By way of illustration, and taking as its premise the assumption that all knowledge is, at least to a certain extent, ideological and related to power, this paper attempts, within the theoretical framework of critical literacy, an analysis of a specific visual discourse relevant to art history studies - the iconography of Hortus Conclusus (Enclosed Garden). Methodologically speaking, the benefits from this kind of approach could be manifold. Students are and feel empowered to critically acquire/deconstruct/reconstruct knowledge in specific content areas - a fact which in itself provides higher motivation in an EAP class (they are primarily focused on gaining knowledge in English rather than that of/about English). All the stages of the above demonstrated process are conducted in English, which gives the teacher an excellent opportunity to cater for the students' specific needs (e.g. employ concept and semantic mapping and other vocabulary-building strategies relevant to their fields of study). The approach also appears to raise the students' overall awareness of language and stimulate an analytical interest in etymology, semantics and semiotics as well as in the nature, purpose and workings of language in general.
\end{abstract}

Key words: critical literacy, visual discourse analysis, Hortus Conclusus, deconstruction, reconstruction, EAP teaching, content areas, motivation, language awareness 
Within the theoretical framework of a critical literacy approach to education (Behrman 2006), (Cervetti et al. 2001), (Gregory \& Cahill 2009) etc., and drawing on some post-modernist and post-structuralist discourse analysis practices, this paper seeks to demonstrate a practice of a visual discourse analysis, in this particular case - of a mediaeval painting, the subject field of art history students to whom the author teaches English at the Belgrade Faculty of the Humanities/Philosophy. Just like any other deconstructive/ reconstructive process, the event itself is unrepeatable and unique. According to Derrida (1985:3), "deconstruction takes place, it is an event". Therefore, this particular analysis merely offers some guidelines/ideas for conducting a similar practice in the classroom.

GARDEN (OE) geard - yard, garth (Guralnik1988:556);

GARDEN c.1300, from O.N.Fr. gardin, from V.L. hortus gardinus "enclosed garden," via Frank. "gardo, from P.Gmc. "gardon (cf. O.Fris. garda, O.H.G. garto, Ger. Garten "garden," O.E. geard "enclosure," see yard. (Harper 2010).

The two words from which the modern garden is derived - yard and garth are both associated with an enclosed space - a place surrounded by a wall which protects those within from intruders and the inquisitive eyes of those without. The wall ensures that no one steals the owners' vegetables or flowers, spoils their pleasure, shares in their enjoyment. Thus, whether it serves the purpose of healing and sustenance, rest and spiritual refuge/ prayer (e.g. monastic herb gardens) or sensual enjoyment and dalliance, the value of the garden is in its privacy, seclusion and inaccessibility. Whatever lies inside the perimeters of the garden has to be watched over and closely guarded in the face of potential adversity outside.

In mediaeval times, when the garden we shall be examining here was created, the farmland attached to a castle was also bounded by a kind of fence, as is shown in these beautiful early $15^{\text {th }}$ century illuminations by the Limbourg brothers (Très Riches Heures du Duc de Berry), whose authority we shall invoke later again. The etymology of fence may be here of interest too: 

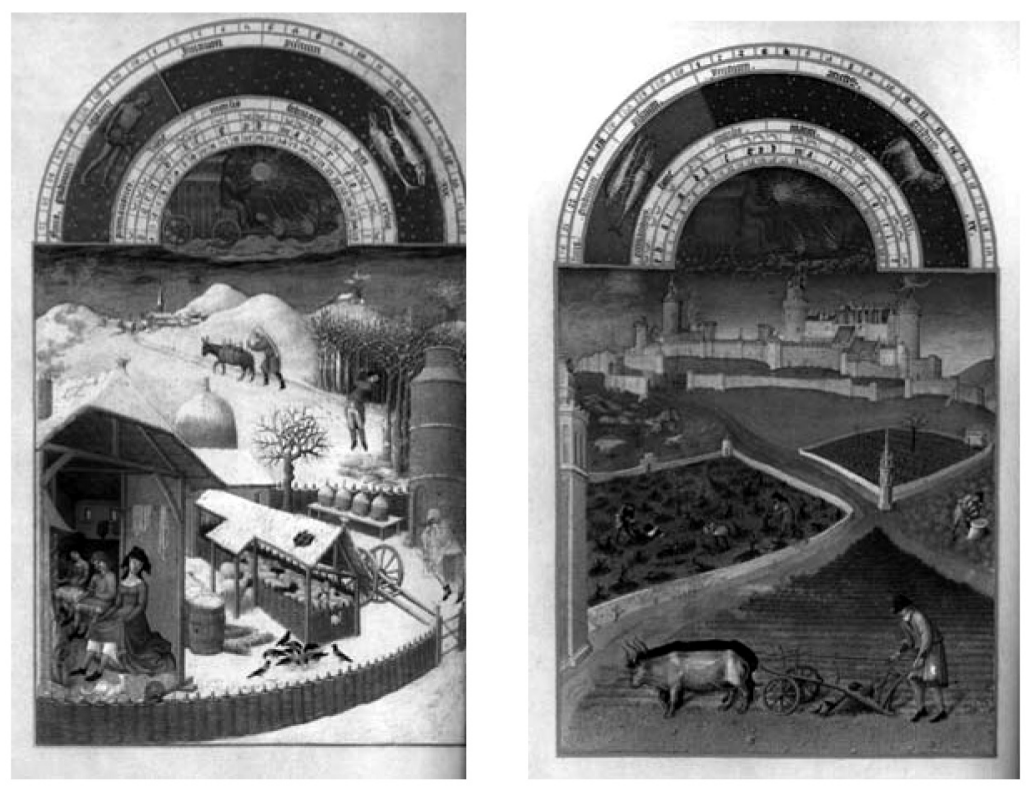

February and March from Très Riches Heures du Duc de Berry, c. 1416, by the Limbourg brothers - Paul, Jean and Herman - Musee Conde, Chantilly, France.

FENCE (n.) early 14c., shortening of defens (see defense). Spelling alternated between $-c$ - and -s- in M.E. Sense of "enclosure" is first recorded in 1510s. Fencible (early 14c.) means "capable of making a defense." Fencing (n.) late 15c., "defending;" 1580s in the sword-fighting sense; prp. of fence(v.). Meaning "putting up fences" is from 1620s; that of "an enclosure" is from 1580s (Harper 2010).

However, the Little Garden of Paradise (by an unknown, Upper Rhenish Master c. 1410) is not merely fenced-in but set within solid walls of a real/imaginary castle, shielding the tranquil world within from the reality/ frequent wars, violence and disease without. The garden also protects its dwellers against other forms of otherness/reality, but more on this later. The paradisiacal scene, along with many similar ones created in the Middle Ages/early Renaissance, is interpreted as Hortus Conclusus - a common, though relatively short-lived iconographic theme in Western European painting. 


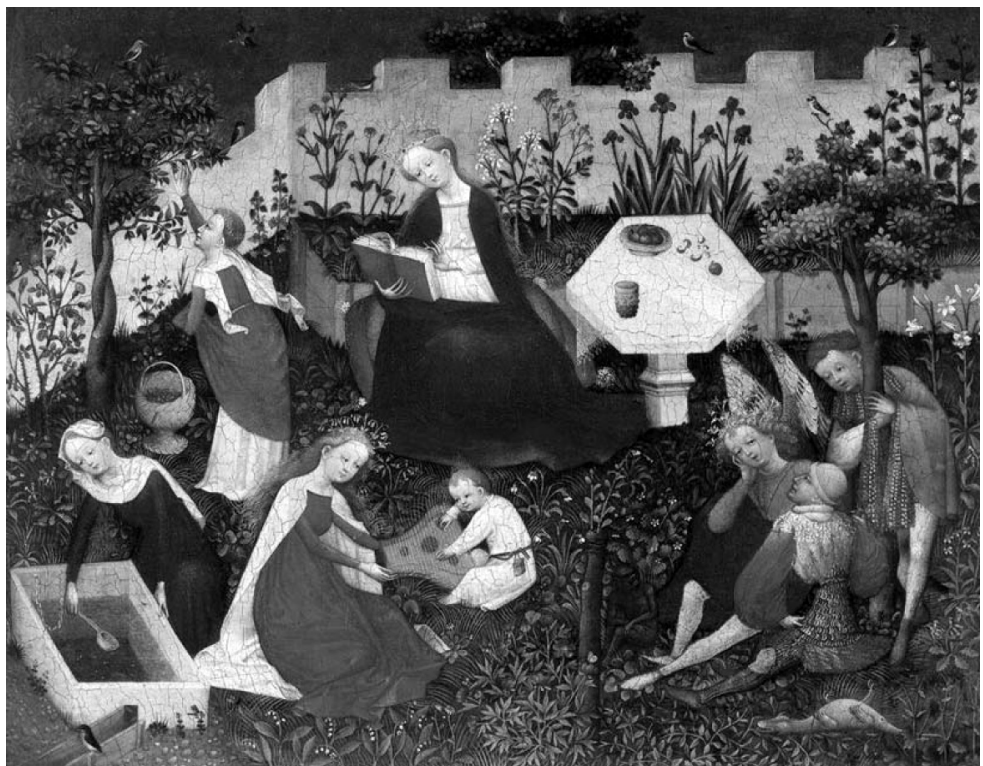

Little Garden of Paradise (by an unknown, Upper Rhenish Master c. 1410)

Stadelsches Kunstinstitut und Stadtische Galerie, Frankfurt am Main

The term hortus conclusus is derived from the Vulgate Bible's Canticle of Canticles (also called the Song of Songs or Song of Solomon) 4:12, in Lat: Hortus conclusus soror mea, sponsa, hortus conclusus, fons signatus ('A garden enclosed is my sister, my spouse; a garden enclosed, a fountain sealed up'). Christianity reinterpreted what was originally construed by some scholars as Solomon's nuptial song to his bride as the love and union between Christ and the Church. Furthermore, the verse "Thou art all fair, my love; there is no spot in thee." (4:7) from the Song was seen as a scriptural confirmation of the doctrine of Mary's Immaculate Conception, i.e. of her being born without Original Sin (macula - Lat. 'spot'). Medieval theologians interpreted the reference as a prefiguration of Mary's fruitfulness combined with her perpetual virginity (like the 'shut gate', Porta clausa, through which only God may enter, from the vision of Ezekiel). The symbolism was developed by numerous artists and inspired, especially in later medieval art, images of the Madonna and Child seated in a beautiful garden, often abounding in trees and flowers and surrounded by walls. Sometimes a fountain (the 'spring shut up', 'fountain sealed' 'well of living waters') from the Song of 
Songs and angels were also represented. Mary is occasionally depicted in the company of a unicorn - another symbol of her purity . In late medieval art, this depiction was sometimes conflated with that of the Annunciation, which explains the presence of Archangel Gabriel somewhere inside or outside the garden enclosure.

Now may be the time to ask, as part of the deconstruction process, some of the questions underpinning the critical literacy approach advocated by the author of this paper:

What are the assumptions and potential implications of the (visual/written) statements?

How is reality defined?

Who defines it?

In whose name?

For whose benefit?

What are the limitations or contradictions of this perspective?

How could these statements (or words) be interpreted in different contexts?

(Cervetti et al. 2001).

Or to quote Derrida (1978):

" [...] But what is thematic attention? And does what it seems to exclude (the implicit? the foreclosed? the denied? the unthought? the encrypted? the 'incorporated'? - so many different functions) allow itself to be excluded from the field?

From what field? Fenced by whom? By what?... ."

In order to answer these questions (and bearing in mind that there are numerous possible ways of answering them) students will need to read supplementary texts, as well as use their analytical/critical skills and imagination.

For example, the picture in question certainly exludes, implicitly or explicitly, several social classes and groups. The style of clothing shown here was reserved for upper-class men and women as can be seen in other paintings from that period, e.g. illuminations by the Limbourg brothers. Barred from this paradise are the physically non-perfect, too: all the protagonists in the picture conform to the mediaeval /upper-class/ ideal of beauty, there is no room for any kind of otherness. Their genteel golden-haired long-fingered beauty, which supposedly reflects their inner, spiritual beauty, is, incidentally, sexless - the only thing that sets the men 
apart from the women is the colour of their skin, slightly darker in hue, an aesthetic and artistic canon practised in other cultures as well, such as those of ancient Egypt and Greece. Excluded are not only the non-virtuous Christians but also the followers of other religions, irrespective of their virtue: they did not conceive of paradise in the same way and could/would not have been admitted into this one anyway. Furthermore, foreclosed is the reality outside: frequent wars accompanied by plunder, poverty, death and the sense of insecurity; recurrent floods, droughts, poor harvest, famine and raging epidemics, "[...] excrement on the roads, stray dogs and pigs everywhere, the stench, cramped gloom and cold of the dwellings" (Hagen 2001:12). Within 10 years of starting to work for Duc de Berry, all the three Limbourg brothers themselves were dead, presumably the victims of an epidemic, and their beautiful Book of Hours was never finished.

Even though the lower classes do not have access to this divine, privileged garden, the hierarchy does not stop there - it exists in heaven, too. The largest figure is that of Mary, who is sitting just below the terraced part of the lawn (probably reserved for someone even higher in rank in this celestial hierarchy). Contemporary spectators, again like ancient Egyptians, Byzantines etc., attached considerable importance to the relative height at which a figure sat. Mary is reading a book-something that not many women of her time would have been able to do. Whilst noble women did receive some private tuition and some were able to read (though not necessarily write), and whilst nunneries did provide a few schools and a rudimentary education, most peasant women were illiterate (Hallam 2002:266). Not that many men of the same social rank were literate, either. Incidentally, if Mary did exist - a fact which archaeology can neither prove nor disprove, she herself would almost certainly not have been literate. But our garden goes beyond the competence of archaeology and exists in a metaphorical space created by faith and Church dogma, as well as by several other factors to which we return later in the paper.

To Mary's left is St. Dorothy, shown in profile and picking cherries. St. Barbara is represented drawing water from a spring and the woman holding a psaltery and playing with the child Jesus is probably St. Catherine of Alexandria. The winged figure is Archangel Michael - the one who triumphed over the demons and devils - one of whom, an adorable creature, rather resembling a little black forest sprite or gollywog, is sitting obediently, small and powerless, at his feet. St. George, wearing chain mail and greaves, is shown with his trophy, the dragon he defeated when 
saving a virginal princess. Like the devil previously, the dragon is shrunk here to a mere symbol as befits its role and importance in Paradise. The mediaeval spectator would not have had too much trouble identifying figures in religious paintings by their activities/symbols/ instruments of passion which, in turn, alluded to their miracles/legend/ martyrdom. By contrast, the modern viewer is pretty much at a loss, lacking the religious, traditional and cultural background which would enable him/her to decode the pictorial symbols. And indeed, most contemporary, $15^{\text {th }}$ century nonEuropean viewers of the painting,

would have been faced with the same problem.

"Fenced by whom/what?" (Derrida 1978:441)

Certainly by Christian doctrine/Church dogma of the period; by the author's background and personality; the mores/fashion of the time; the commissioner's/ patron's needs and preferences. Although other figures in the picture can be identified with relative ease, the identity of the standing male figure remains obscure. There is a little black bird just behind his knees. It has been suggested that the bird symbolizes death, and that the picture commemorates this young man's demise. In any case, both the identity of the painter and that of the patron remain unknown. Its small format (26.3x33.4) though, suggests it was intended to hang in a private home rather than in a church. Finally, what also comes into the complicated intertextual equation, is the reader/viewer himself (his culture, background, education, gender, age, motivation etc).

"And does what it seems to exclude (the implicit? the foreclosed? the denied? the unthought? the encrypted? the 'incorporated'? - so many different functions) allow itself to be excluded from the field?" (Derrida 1978:441)

"[...] Thus, Paradise is not only represented by the garden but also by Mary herself: like Paradise, where sexuality does not exist, Mary's immaculate conception places her in a permanently paradisiacal state". (Hagen 2001:12). Furthermore, "Walls do not usually have a place in Paradise, but this one symbolizes Mary's virginity,[...] for, according to Christian belief, Mary conceived without penetration" (Hagen, 2001:12). Incidentally, an interesting attempt to create a visual explanation of the mysterious event - Conceptio per aurem ('Conception through the ear') - was made in some North-European types of the Annunciation (again, usually in an enclosed setting, which is why this type is also seen as a 
variant of Hortus Conclusus), where the Word (Logos) enters the Virgin through her right ear in the form of divine rays - in the midst of which the Holy Ghost is sometimes suspended.

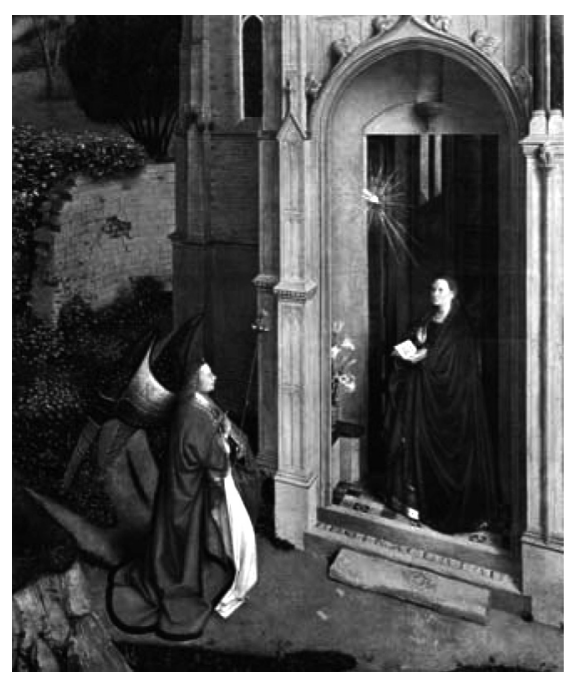

Annunciation by Jan Van Eyck (1425-30), The National Gallery of Art, Washington DC, USA.

Does the Little Garden of Paradise exclude sensuality/sexuality? Sensuality is certainly present here, if not in the depiction of the figures than certainly in the depiction of the birds and flowers. Naturally, most of them are here for a reason. White lilies represent Mary's purity; red roses (with no thorns) and irises are also her attributes. But it is the sheer beauty of the garden, with its harmony and naiveté, its brilliant colours and imagined scents that still resonates today, even if the symbolism of the painting is somewhat lost on the modern spectator. Did the patron (whoever he was) intend sensuality to find its way into the picture, or is it the case of the painter himself deciding to give full rein to his imagination, artistry and sensuality, relishing the botanical detail - one of the few things he was allowed to do, and even pursuing an interest in zoology? As a matter of interest, scientists have identified at least ten different species of birds and twenty species of plants in the picture. What springs to mind when contemplating this picture is Arabic miniatures/illuminations with no human figures (since they were banned) but with a plethora of beautifully 
stylized, often bordering on abstract, floral and geometric motifs, both spiritual and sensual at the same time. Could these have evolved from the same source?

In order to proceed with answering the question concerning the presence of sensuality/sexuality in the picture, we again have to invoke intertextuality, that is, we cannot ignore the source from which the symbolism of the Virgin is derived. Let us remind ourselves of some of the verses from the Song:

Let him kiss me with the kisses of his mouth: for thy love is better than wine. $(1: 2)$

A bundle of myrrh is my well-beloved unto me; he shall lie all night betwixt my breasts. (1:13)

His left hand is under my head, and his right hand doth embrace me. $(2: 4)$

Thy lips are like a thread of scarlet, and thy speech is comely: thy temples are like a piece of a pomegranate within thy locks. $(4: 3)$

Thy two breasts are like two young roes that are twins, which feed among the lilies. (4:3)

How fair is thy love, my sister, my spouse! how much better is thy love than wine! and the smell of thine ointments than all spices! (4:3)

Awake, O north wind; and come, thou south; blow upon my garden, that the spices thereof may flow out. Let my beloved come into his garden, and eat his pleasant fruits. (4:16)

My beloved put in his hand by the hole of the door, and my bowels were moved for him. $(5: 4)$

How beautiful are thy feet with shoes, O prince's daughter! the joints of thy thighs are like jewels, the work of the hands of a cunning workman. (7:1)

Thy navel is like a round goblet, which wanteth not liquor: thy belly is like an heap of wheat set about with lilies. (7:2)

Thy two breasts are like two young roes that are twins. (7:3)

This thy stature is like to a palm tree, and thy breasts to clusters of grapes. (7:7)

I said, I will go up to the palm tree, I will take hold of the boughs thereof: now also thy breasts shall be as clusters of the vine, and the smell of thy nose like apples; (7:8) 
And the roof of thy mouth like the best wine for my beloved, that goeth down sweetly, causing the lips of those that are asleep to speak. (7:9)

I am my beloved's, and his desire is toward me. (7:10)

Whatever the allegoric and symbolic interpretations (both by Jewish and Christian scholars) of the Song are, contemporary analyses most often focus on its obvious eroticism and sensuality, a feature which the Song is believed to share with some other ancient Near Eastern love poetry (e.g. Sumerian and Ramesside Egyptian erotic passages). By contrast, the atmosphere rendered in the Little Garden of Paradise seems to be incomparably more chaste and virginal, and its protagonists more demure, than is the case with the source from which its symbolism is derived. In this sense, the ideas it conveys are not unlike those of courtly love, exalted and idealized in contemporary mediaeval troubadour poetry: though eternal bliss/love is something one should strive for, it is unattainable in this life; suffering is preferable to consummation; the ultimate reward for virtue is spiritual/ platonic rather than sensual/ material; salvation comes from the hands of Mary, who stands for the Church/the virtuous mistress. Like the Garden, courtly love was exclusive too. Only knights (that is, men of relatively noble origin) were deemed to be eligible lovers. The ideal lady was usually the Lord's wife, and though the knight's loyalty was always to his Lord before his mistress and pleasures of the flesh did not, supposedly, come into this kind of relationship, the husband was excluded from it - yet, paradoxically, his existence was a prerequisite for the existence of the love itself. Like the Enclosed Garden, courtly love was supposed to be secret and lovers shielded from the eyes of courtiers (except, perhaps, for the select few who enjoyed the confidence of the lovers), so that again, castle/garden walls are a metaphor for inclusion/exclusion.

The famous example of a pair of shoes, repeatedly painted, with some variation, by Van Gogh and referred to and variously interpreted by Heidegger (1935), Shapiro (1994) and Derrida respectively (1978), only goes to show how difficult it is to interpret a work of art with the artist in absentia. And just like Van Gogh's famous shoes, in the absence of the artist, have assumed a metaphysical life of their own, so does our Hortus Conclusus transcend the particular circumstances in which it was painted, thus enabling us to look not just at a single depiction/instance of Hortus Conclusus and its symbology/interpretation, but rather the iconography of 
Hortus Conclusus, and the various depictions/interpretations it included over time.

In some Hortus Conclusus represenations, Mary is depicted in the company of a unicorn - yet another symbol of her purity. According to Bestiaries, the unicorn is a mythical beast, similar to a little white horse or goat, and with a single horn growing from the middle of its head (perhaps it is based distantly on the rhinoceros). Apparently, no hunter could capture it unless he used a trick: he would take a virgin to the spot frequented by the unicorn and leave her alone there. The unicorn, sensing the purity of the maiden, would run to her, lay its head in her lap, and fall asleep. Thus its capture would be effected. For this reason the unicorn is considered a symbol of purity in general and of feminine chastity in particular. This legend was interpreted by Christian writers as an allegory of the Annunciation and the subsequent Incarnation of Christ. Therefore, the unicorn is an emblem of the Virgin Mary, as well as of St. Justina of Padua and St. Justina of Antioch. (Fergusson 1961) The unicorn allows itself to be captured by a virgin; hence the scene Hortus Conclusus, where the Virgin is often represented with a unicorn, is sometimes interpreted as a type of Christ's betrayal.

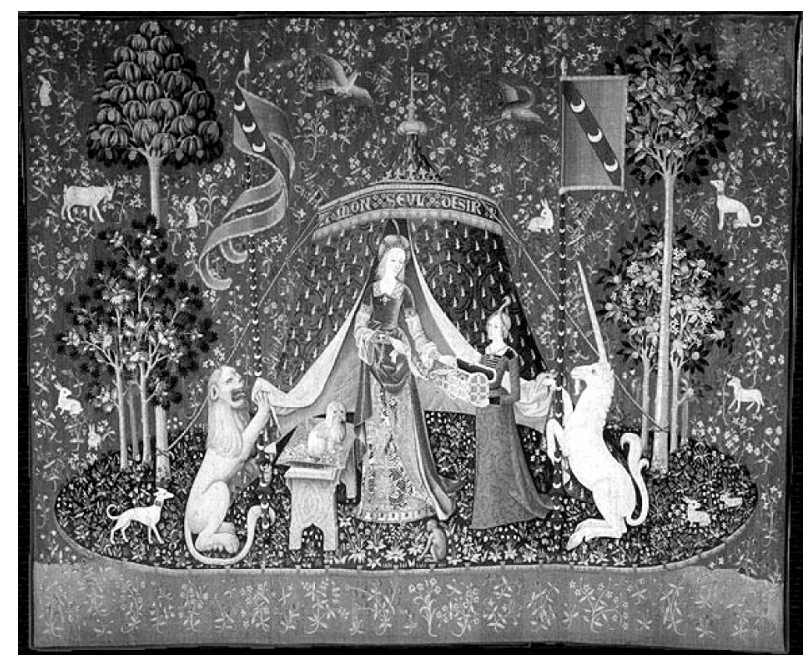

The Lady with the Unicorn (c. 1511) The Cluny Museum, Paris, France. 
Within the theoretical framework of intertextuality and cross-referentiality, and in accordance with Derrida's notion of binary opposition, the unicorn myth lends itself to numerous interpretations. They, naturally, show that this archetypal image represents different things to different people.

The two major interpretations of the unicorn symbol hinge on pagan and Catholic symbolism. The pagan interpretation focuses on the medieval lore of beguiled lovers, whereas some Catholic writings interpret the unicorn and its death as the Passion of Christ... [...] The unicorn also figured in courtly terms: for some 13th century French authors such as Thibaut of Champagne and Richard de Fournival, the lover is attracted to his lady as the unicorn is to the virgin (Wikepedia 2010).
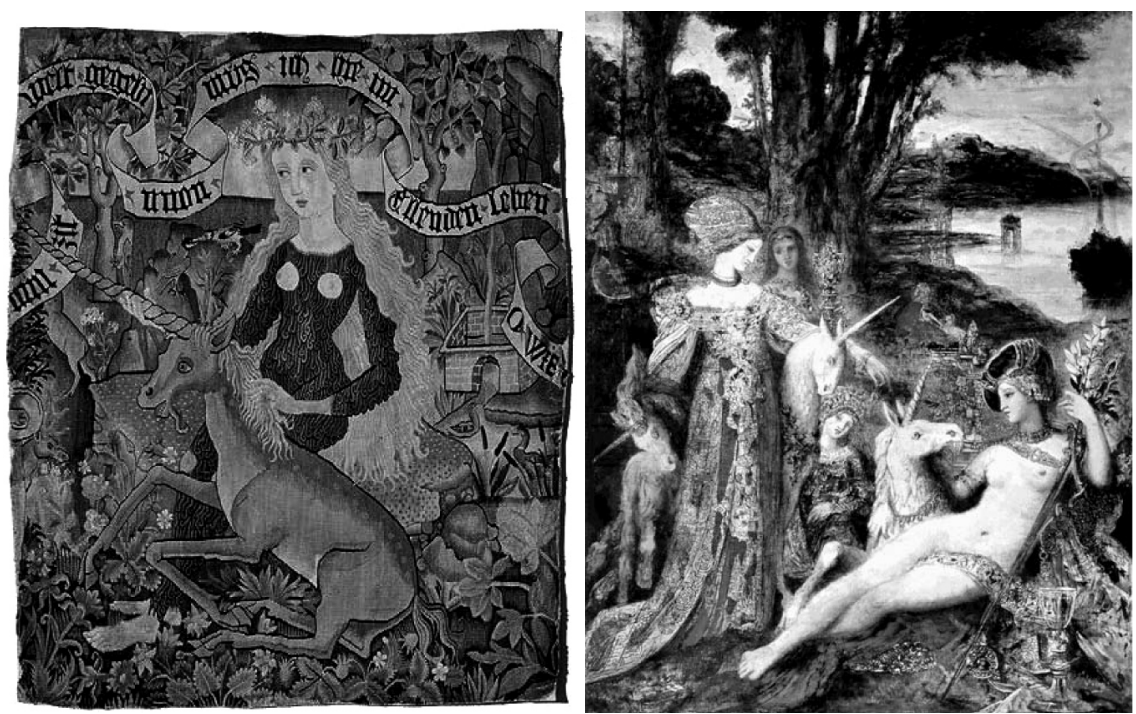

Wild Woman with Unicorn (c. 1500-1510, Historisches Museum, Basel, Germany); The Unicorns by Gustave Moreau (1826 - 1898), Musee Gustave Moreau, Paris, France.

Confirmation that the unicorn has not been always been associated with chastity and purity can, for example, be found in Wild Woman with Unicorn (c. 1500-1510, Basel, Historisches Museum), a tapestry depicting what is basically a Physiologus story, combined perhaps with some pagan lore or embroidered on by the author himself: it certainly does not seem to have much in common with the strictly Christian interpretation of the myth 
- i.e. at least not in terms of the associations it evokes. The representation itself is not new. It harks back to some Greek myths in which gods or semi gods appear as horned animals (Europa and the Bull, Pasiphae and the Bull etc.) Anyway, whether someone within the Church found the pictorial interpretations of the Unicorn Hunt allegory not entirely plausible, or whether the symbolism reeked too much of paganism and evoked too many Freudean associations, to use modern terminology, the scene was prohibited by the Tridentine Council in 1563 - though, fortunately, not before finding its way onto some of the most beautiful tapestries of that time.

And the iconography of the Garden of Paradise itself disappeared by the end of the $15^{\text {th }}$ century: "a late blossom, embedded in a mediaeval language of symbols" Hagen (2001:16). The best example of its binary opposite, both visually and philosophically speaking, can perhaps be found in either of the two panels of the famous Bosch triptych - "The Garden of Earthly Delights". Whilst one wing indisputably represents paradise, and the other - hell, what exactly the central panel is meant to represent still remains a moot point.

The scene that replaced the Garden of Paradise was the Garden of Love, originally a literary topos (e.g. the Decameron) which proved to be a popular subject in painting as well, and as such persevered for centuries to come. This worldly garden often represents the very opposite of the sublime tranquility of Christian paradise as seen above.

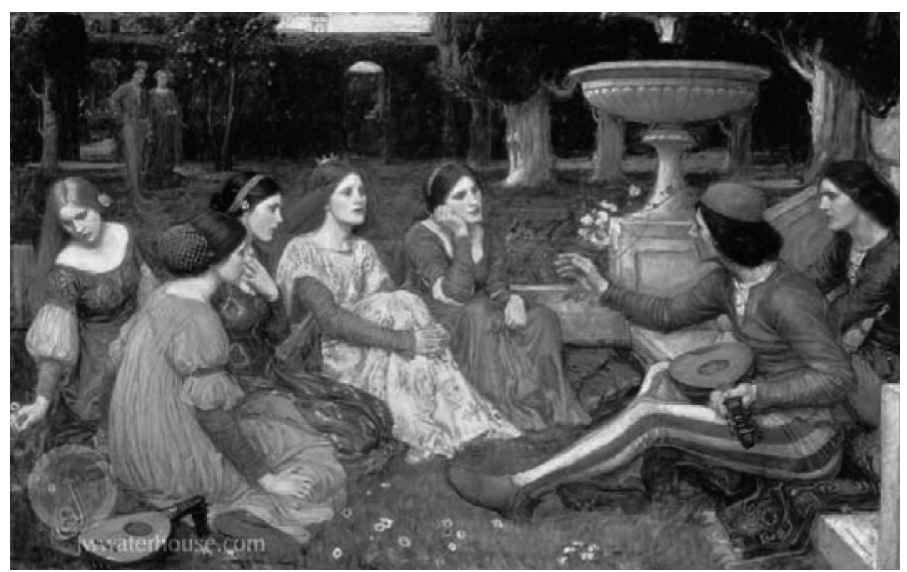

A Tale from the Decameron by J.W.Waterhouse (1916), Lady Lever Art Gallery, Liverpool, UK. 
During the deconstructive stage of the analysis, and in order to be able to address the questions posed above (for the above analysis represents merely one point of view) students are encouraged to read supplementary texts as well as engage in reading multiple texts and reading from a resistant perspective. Students gain multiple perspectives of the same event by considering how people from different backgrounds - cultural, religious, socio-economic, gender, sexual orientation etc. - would read the same text; they are encouraged to interpret the text from the viewpoint of the world and not just the common Eurocentric ideology usually found in standard texts (Behrman: 2006).

Supplementary material, analysis and discussion:

-The Abbey in the Oakwood, painting by Caspar David

Friedrich

-The Garden of Love, poem by William Blake

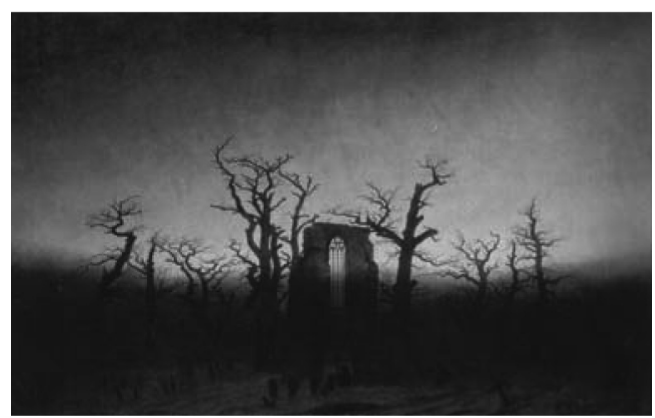

The Abbey in the Oakwood, Caspar David Friedrich (1808-10), Alte Nationalgalerie, Berlin, Germany

Further questions can be asked along the following lines:

Is the Garden of Love essentially an anti-Christian concept, and is

the Christian/ Church dogma-conceived garden necessarily an anti-Garden of Love concept?

When can an enclosed garden appear as totally different from/ the opposite of/our paradisiacal garden? Inverted perspective: while an enclosed garden may appear to be an object of desire to those who are excluded from it, and a place of shelter/refuge/source of pleasure to those within, it can also appear as a claustrophobic, prison-like space to those doomed to live inside its walls - a place of confinement/captivity: e.g. Van Gogh - the suffocating 
enclosedness of the Arles Hospital courtyard; Napoleon Bonaparte tending his garden in exile on the Island of Saint Helena; Mary Stuart, hoping and biding her time for 19 years in custody in various gardens of castles and manor houses etc. Also: enclosure as prison/ hell/ concentration camp (e.g. Hell, painting by Chapman brothers).

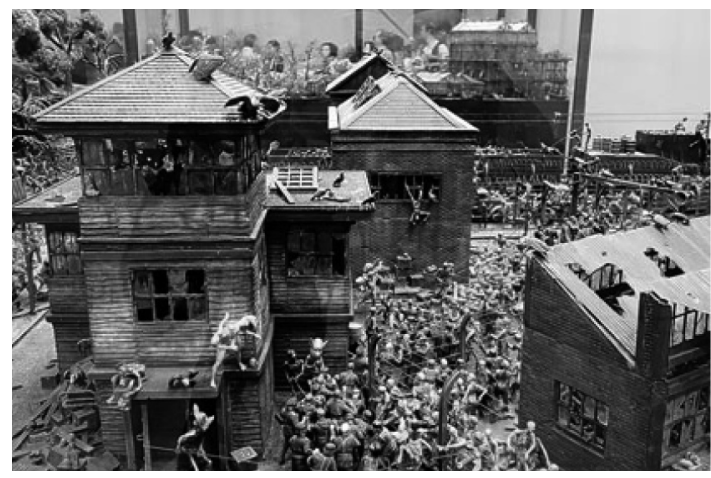

Courtyard of the Hospital in Arles by Van Gogh (1889) Oscar Reinhart Collection, Winterthur, Switzerland and the Chapman brothers' vision of Hell (reworked version)

How do you see the world beyond the walls of the garden? And how do those beyond the walls of the garden see/ imagine the space inside? How do Oriental gardens (and people/objects inside) appear to the non-Oriental eye? And viceversa.

At reconstruction stage, students are invited to create a new text i.e. create their own garden/park, visually or verbally, by changing the context/ perspective or giving voice to a hitherto silenced speaker. McLaughlin and DeVoogd (2004: 52-62) recommend switching as a strategy. Thus, they propose a setting switch (different time, place, class), ethnic/race switch, gender switch, culture switch, a theme switch (creating a text with the opposite theme) etc.

Incidentally, just like another piece of the puzzle that falls into place, the etymology of park ties in with that of garden/fence:

PARK (n.) c.1260, "enclosed preserve for beasts of the chase," from O.Fr. parc, probably ult. from W.Gmc. "parruk "enclosed tract of land" (cf. O.E. pearruc, root of paddock (2), O.H.G. pfarrih "fencing about, enclosure," Ger. pferch "fold for sheep," Du. 
park). Internal evidence suggests the W.Gmc. word is pre-4c. and originally meant the fencing, not the place enclosed. Found also in M.L. parricus "enclosure, park" (8c.), which is likely the direct source of the O.Fr. word, as well as It. parco, Sp. parque, etc. Some claim the M.L. word as the source of the W.Gmc., but the reverse seems more likely. OED discounts notion of a Celtic origin. Welsh parc, Gael. pairc are from English. As a surname, Parker "keeper of a park" is attested in Eng. from c.1145. Meaning "enclosed lot in or near a town, for public recreation" is first attested 1663, originally in ref. to London (Harper: 2010).

The resituation of the canon and the recreation of the garden by the students may yield interesting results. Linguistically and ideologically speaking, the road is thus paved for traversing time and space from a fenced area/garden/park/hortus conclusus of the past to a modern concept of it, or rather, to a multitude of modern concepts of it. And with some luck, there will be, at least, a few paths leading off that road, and into that much coveted place which exists more often in our dreams than in real life, a hortus apertus, a more open, more inclusive and more tolerant, multicultural garden /society/reality, conceived and created by the students themselves.

On a final note, and purely methodologically speaking, the benefits from this kind of approach are manifold. Students are and feel empowered to critically acquire/deconstruct/reconstruct knowledge in their content areas - a fact which in itself provides higher motivation in an EAP class (they are primarily focused on gaining knowledge in English rather than that of/about English). All the stages of the above demonstrated process are conducted in English (research, class interaction etc), which gives the teacher an excellent opportunity to cater for the students' specific needs (e.g. employ concept and semantic mapping and other vocabularybuilding strategies relevant to their fields of study). The approach also appears to raise the students' overall awareness of language and stimulate an analytical interest in etymology, semantics and semiotics as well as in the nature, purpose and workings of language in general. 


\section{References}

Behrman, E. (2006). Teaching about language, power, and text: A review of classroom practices that support critical literacy, Journal of Adolescent and Adult Literacy 49, 490-98.

Cervetti G., Pardales, J.M. \& Damico, S.J. (2001). A Tale of Differences: Comparing the Traditions, Perspectives and Educational Goals of Critical Reading and Critical Literacy. (Sept 15, 2009) <htpp://www. readingonline.com $>$

Ciardiello, A.V. (2004). Democracy's young heroes: An instructional model of critical literacy practices. Reading Teacher, 58, 138-147.

Coffey, H. (2008). Critical Literacy. (Jan 25, 2010) < http://www.learnnc. org/lp>.

Derrida, J. (1978). Restitutions of the Truth in Pointing ['Pointure']. Trans. Geoffrey B. \& McLeod, I. Chicago \& London: Chicago University Press.

Derrida, J. (1985). Letter to a Japanese Friend, in Wood\&Bernasconi (Eds.), Derrida and Differance. Warwick: Paroussia Press.

Fergusson, G. (1961). Signs and Symbols in Christian Art. Oxford: OUP.

Gregory E. A., Cahill. A. M. (2009). Constructing critical literacy: self reflexive ways for curriculum and pedagogy. Critical Literacy: Theories and Practices, Vol 3:2.

Guralnik, B.D. and V. Neufeldt (eds.) (1988). Webster's New World Dictionary. New York: Webster's New World Dictionaries.

Hagen, R.M. \& R. (2001). 15 ${ }^{\text {th }}$ Century Paintings, Cologne: Taschen.

Harper, D. Online Etymology Dictionary (C) 2001-2010. (January 5, 2010) <htpp://www.etymonline.com/columns/bio.html>

Heidegger, M. (1935). The Origin of the Work of Art. Off the Beaten Track (Cambridge: Cambridge University Press, 2002). Translation of Holzwege (Frankfurt: Vittorio Klostermann, 1950), vol. 5 in Heidegger's Gesamtausgabe.

Hallam, E. (general ed.) (2002). Chronicles of the Age of Chivalry. London: Salamander Books Ltd.

Schapiro, M. 1994. The Still Life as a Personal Object - A Note on Heidegger and van Gogh; Further Notes on Heidegger and van Gogh, in: Theory and Philosophy of Art: Style, Artist, and Society, Selected papers 4, New York: George Braziller, 135-142; 143-151.

Wikipedia. Unicorn, (Jan 5, 2010) < http://en. org/wiki/Unicorn> 


\section{Милица Стојановић}

Универзитет у Београду, Србија

\section{HORTUS CONCLUSUS: АНАЛИЗА ВИЗУЕЛНОГ ДИСКУРСА ЗАСНОВАНА НА ТЕОРИЈИ КРИТИЧКЕ ПИСМЕНОСТИ КАО ОБРАЗОВНОМ ПРИСТУПУ}

\section{Сажетак}

Развијање способности критичке писмености данас је за студенте неопходност без обзира на област студирања. Ово особито долази до изражаја у друштвеним наукама јер се баш у овим областима, са различитих аспеката - историјских, културних, критичких итд. - многа гледишта и судови непрестано преиспитују, ревидирају, деконструишу и реконструишу у складу са временом и постмодерним\ модерним теоријама. Крећући се у оквиру теорије критичке писменоси, и полазећи од претпоставке да је све знање, барем у извесној мери, идеолошко и да одражава моћ, овај рад даје пример анализе иконографски специфичног ликовног дискурса релевантног за студенте историје уметности (Hortus Conclusus) примењене у оквиру наставе енглеског језика на Филозофском факултету у Београду. У оквиру рада наводи се и које су методолошке предности једног оваквог приступа настави енглеског језика\језика струке на академском нивоу.

Кључне речи: критичка писменост, анализа ликовног дискурса, Hortus Conclusus, деконструкција, реконструкција, настава енглеског на академском нивоу, садржаји из одређене струке, мотивација, свест о језику 